\title{
Mortality of iron miners in Lorraine (France): relations between lung function and respiratory symptoms and subsequent mortality
}

\author{
N Chau, L Benamghar, Q T Pham, D Teculescu, E Rebstock, J M Mur
}

\begin{abstract}
An increased mortality from lung and stomach cancer was found in previous studies on Lorraine iron miners. A detailed analysis, however, was not possible due to the lack of data for survivors. In this study the cohort included 1178 workers selected at random from all the 5300 working miners aged between 35 and 55 at the start of the follow up period, which ranged from 1975 to 1985 . Occupational exposures and tobacco consumption, lung function tests, and respiratory symptoms were assessed for each subject in 1975,1980 , and 1985 . This study confirmed the excess of lung cancer (standardised mortality ratio $(S M R)=389, p<0.001$ ) and of stomach cancer $(S M R=273, p<0.05)$. There was no excess of lung cancer in non-smokers and moderate smokers ( $<20$ pack-years) or the miners who worked only at the surface or underground for less than 20 years. A significant excess $(S M R=349, p<0.001)$ was found in moderate smokers when they worked underground for between 20 and 29 years. Heavy smokers (over 30 pack-years) or subjects who worked underground for more than 30 years experienced a high risk: $S M R=478$ $(p<0.001)$ for moderate smokers who worked underground for over 30 years; 588 ( $p<0.001)$ for heavy smokers who worked underground for between 20 and 29 years; and 877 (p < $0.001)$ for heavy smokers who worked underground for over 30 years. This showed an interaction between smoking and occupational exposure. The excess mortality from lung cancer was because there were some subjects who died young (from 45 years old).
\end{abstract}

INSERM U115 "Santé an Travail et Santé Publique: Méthodes et Applications, Faculte de Médecine, BP 184, 54505 Vandoseuvre -lis-Nancy Cadex, France N Chau, L Benamghar, Q T Pham, D Teculescu, E Rebstock, J M Mur
Comparison with the results of a previous study showed that additional hazards produced by diesel engines and explosives increased the mortality from lung cancer. The SMR was higher than $400(p<0.001)$ from 45 years old instead of from 56 years. A relation was found between a decrease in vital capacity (VC), forced expiratory volume in one second $\left(F E V_{1}\right)$ and of $F E V_{1} / V C$ and mortality from all causes and from lung cancer in heavy smokers or men who had worked underground for more than 20 years. Respiratory symptoms were related to mortality from lung cancer among smokers (moderate and heavy) who worked underground for more than 20 years. It is considered that the risk of lung cancer in the Lorraine iron miners was mainly due to dust, diesel engines, and explosives although the role of low exposure to radon daughters could not be totally excluded.

\section{(British fournal of Industrial Medicine 1993;50:1017-1031)}

Investigations conducted in many countries reported an excess of mortality from lung cancer among iron ore miners. ${ }^{1-25}$ Only a few studies showed an increased risk of stomach cancer. ${ }^{171920}$ Iron ore miners are exposed to several occupational hazards but these were generally not measured in detail. As in uranium mines, ${ }^{426} 27$ some authors attributed much of the risk of lung cancer to radon daughters even if the dose was low. ${ }^{1345-8}$ Other investigators however, suspected dust and other hazards. ${ }^{10-14}{ }^{16-19}$ Chen et al indicated that it has not been possible to evaluate the relative roles of dust and of radon daughters due to an overlap of exposure to both hazards. ${ }^{21}$ There were also other hazards produced by machinery and explosives (polycyclic aromatic hydrocarbons, diesel fuel, $\mathrm{CO}$, $\mathrm{NO}_{x}, \mathrm{SO}_{2}$, etc) and smoking. Interaction between smoking and occupational exposure was investigated by several researchers. ${ }^{4829}$ Despite many other studies conducted on mice and hamsters, ${ }^{30-34}$ the effects of various hazards have not been totally elucidated. 
In France, the iron ore miners of Lorraine have been investigated by several researchers. ${ }^{12-20} \mathrm{~A}$ study by Mur et $a l^{16}$ reported a significant excess of mortality from lung cancer $2 \cdot 2$ times higher than expected in reference to French male mortality. In 1975, Pham et al conducted a study on $1178 \mathrm{~min}-$ ers selected at random from among 5300 working miners aged between 35 and $55 .{ }^{11-13}$ The cohort was re-examined in 1980 and in 1985 with the same protocol including an interview about respiratory symptoms and occupational exposure during working life, and lung function tests. This cohort showed for the 1975-80 period an increased death rate for lung cancer (13 observed deaths, standardised mortality ratio, (SMR) 351, p < 0.05) and for stomach cancer (three observed deaths, SMR 375, NS) in reference to the French male population. The number of deaths that occurred, however, was small. The present study analysed mortality of the same cohort with a longer follow up period (from 1 January 1975 to 31 December 1985). Interaction between occupational exposure and smoking was examined. As in other studies ${ }^{35-37}$ we also analysed the relations between lung function, respiratory symptoms in 1975, and subsequent mortality during the observation period.

\section{Materials and methods}

The cohort consisted of 1178 workers selected at random from all the 5300 working miners aged between 35 and 55 who had worked in the iron ore mines of Lorraine for more than five years and who had normal pulmonary $x$ ray films and no chronic cardiovascular diseases. ${ }^{11}$ All the subjects attended a medical examination at the mine's occupational health centre. The protocol included an interview with the standard respiratory questionnaire for the study of chronic bronchitis and pulmonary emphysema of the European Steel and Coal Commission of the EC,,$^{38}$ and lung function tests with a water sealed 81 bell spirograph (Boulitte type $\mathrm{N}$ ). ${ }^{15}$ The tests included three to five measures of vital capacity (VC), three forced expiratory tests for determination of forced expiratory volume in one second $\left(F V_{1}\right)$. Only the highest values were considered. The predicted values were those recommended by the EC for spirometry. ${ }^{39}$

Chronic bronchitis and asthma were defined according to the American Thoracic Society. ${ }^{40}$ Tobacco consumption was measured in pack-years independently at each medical examination (1975, 1980, and 1985). This work, however, took into consideration that assessed in 1975 only but tobacco consumptions measured at the three times did not greatly differ due to an effective antismoking campaign conducted since 1975. Nonsmokers were subjects who had never smoked. Due to the small numbers ex-smokers and current smokers were grouped together.

The protocol also included a standardised questionnaire on occupational exposure during the workers' careers (particularly for different jobs underground) and measurements of various hazards in some workplaces (total and respirable dusts (diameter $<5 \mu \mathrm{m}$ ), $\mathrm{NO}_{x}, \mathrm{CO}$ ), temperature, and humidity). Methods of measurement of hazards and results were provided by Pham et al. ${ }^{11215}$ Amounts of radioactivity due to radon daughters were known from an analysis made in these mines during a research programme on radioactivity in non-uranium bearing mines in Europe. ${ }^{41}$

In 1980 and 1985 the subjects were invited to attend a similar medical examination at the mine's occupational health centre. The follow up was conducted by the mine medical officer. The protocol was conducted by the same medical team from our laboratory.

In this study, subjects who were less than 35 years old or more than 55 years old were excluded as were those whose lung function was not assessed in 1975 (39 men (3.3\%)). Also, 41 workers were lost to follow up in 1980 . They were consequently excluded from this study. Finally, the study cohort included 1098 miners. By 1985, we had lost contact with 78 subjects; these workers were included in the study only for the period $1975-80$. The follow up was from 1 January 1975 to 31 December 1985. During this period, 97 deaths occurred $(8 \cdot 8 \%)$. Causes of deaths were established from hospital records or attending medical practitioners and for a few cases from relatives. Only the main cause of death was considered. It was coded according to the 9th revision of the International Classification of Diseases. ${ }^{42}$

\section{OCCUPATIONAL EXPOSURE}

Occupational exposure was expressed in terms of the total duration of work underground during working life. It was assessed at each medical examination $(1975,1980$, and 1985). This was with regard to measurements of various hazards in different workplaces which were carried out only at the start of the follow up. Calculation of the SMRs ${ }^{43}$ took into account evolution of the duration of work underground during the follow up period. For dead subjects we did not know occupational exposure between the last medical examination and the time of death. Thus the duration of work underground was slightly underestimated for these miners $(2.5$ years on average because the duration between two successive medical examinations was five years).

STATISTICAL METHODS

Mortality analysis was carried out with the $\operatorname{SMR}(\%)^{43}$ with reference to the French male 
population. ${ }^{44}$ The SMRs were calculated for five year age groups for each year of the follow up. To assess the risk of one group compared with another we calculated the relative risk and its $95 \%$ confidence interval $(95 \% \mathrm{CI})$. The relative risk was defined by the ratio of SMRs when they were significant. This method should be valid because the subjects of different groups had similar ages. All the statistical tests were carried out with a first order risk of 0.05 excluding the non-responses. When numbers were small we have also indicated the values of the SMRs not significantly different from $100 \%$ when $p<0 \cdot 10$ (values significant for unilateral test).

Analyses of the relations between lung function and the presence of a respiratory symptom in 1975 and subsequent mortality were made with the SMRs. We also calculated sensibility, specificity, Youden index (equal to sensibility + specificity 1 ), and predictive values of a decrease in a lung function index or of the presence of a respiratory symptom..$^{46}$ The calculations of the SMRs were carried out with a program written in our laboratory. The other statistical analyses were done with FoxPro ${ }^{47}$ and SPSS $^{48}$ programs.

\section{Results}

The study sample consisted of 1098 miners (table 1). At the start of the investigation (1975) $88.2 \%$ of them were aged more than 40 and $68.3 \%$ of the miners had already worked underground for more than 20 years. At the end of the follow up, most of the subjects were retired. ${ }^{18}$ The frequency of smokers was close to that in the French male population $\left(82.9 \% v\right.$ about $\left.80 \%{ }^{49}\right)$.

During the 11 year follow up period, 97 deaths occurred and the date of death was unknown for eight of them. They were excluded in the calculation of the SMRs. Thus the overall SMR calculated

Table 1 Distribution (\%) of the 1098 miners studied according to age, tobacco consumption, and duration of work underground at the start of the follow up (1975)

\begin{tabular}{lr}
\hline Age: & \\
$35-39$ & $11 \cdot 7$ \\
$40-44$ & $34 \cdot 1$ \\
$45-49$ & $33 \cdot 3$ \\
$50-54$ & $18 \cdot 9$ \\
$\geqslant 55$ & $1 \cdot 9$ \\
Smoking (No of pack-years): & $16 \cdot 9$ \\
Non-smokers & \\
Smokers: & $10 \cdot 2$ \\
$1-9$ & $24 \cdot 9$ \\
$10-19$ & $30 \cdot 2$ \\
$20-29$ & $17 \cdot 8$ \\
$\geqslant 30$ & $13 \cdot 0$ \\
Duration of work underground (y): & $18 \cdot 8$ \\
Surface only & $58 \cdot 7$ \\
$1-19$ & $9 \cdot 6$ \\
$20-29$ & \\
$\geqslant 30$ &
\end{tabular}

with 89 deaths would be underestimated by $8 / 97=$ $8 \cdot 2 \%$. The cause of death was unknown for four deaths only. Table 2 shows the distribution of dead miners according to age at death, duration of work underground at the time of death, and smoking. Lung cancer was the most common $(34.0 \%)$ cause of death.

The eight deaths not taken into account were distributed among several causes of death. Mortality from lung cancer was little affected because among the 33 deaths from this cause the date of death of only one case was unknown (1/33 $=3.0 \%)$. By contrast, mortality from cardiovascular diseases was underestimated by $2 / 16(12.5 \%)$. In terms of occupational exposure, the eight deaths were distributed in various exposure groups: three miners who worked at the surface only, two who worked underground for between 20 and 29 years, and three for more than 30 years.

Table 3 shows that the overall mortality of the cohort was similar to that of the French male population (SMR $=90, \mathrm{NS})$. This value would be close to $100 \%$ when the eight deaths $(8 / 97=8 \cdot 2 \%)$ with an unknown date of death were taken into account. The miners who worked underground for less than 20 years had a low mortality from all causes (SMR $=74, \mathrm{NS}, \mathrm{p}<0 \cdot 10$ ). Only the miners who worked underground for over 30 years had a higher mortality than expected $(S M R=120)$ but it too was not significant.

A significantly increased death rate was found for lung cancer $(S M R=389, p<0.001)$. It increased with the duration of work underground (SMR 0 for subjects who worked only at the surface, and SMR 181 (NS), $423(p<0.001)$, and $625(p<0.001)$ for those who worked underground for less than 20 years, between 20 and 29 years, and more than 30 years) (table 3 ). Miners who worked underground for less than 20 years had an increased death rate from lung cancer $(S M R=181, N S)$, stomach cancer $(S M R=482$, NS, p < 0.10), and cirrhosis of the liver and alcoholism $(S M R=259, \mathrm{NS}, \mathrm{p}<0 \cdot 10)$. The excess number of deaths from these causes was, however, noted only among smokers of more than 20 packyears: SMRs $381(p<0.05)$ for lung cancer, 997 $(p<0.01)$ for stomach cancer, and 569 for cirrhosis of the liver and alcoholism $(p<0.001)$ (table 4).

Although the number of deaths from some causes was small, our results indicate that the mean age at death was lower for lung cancer than for stomach cancer (53 (SD 4) v 55 (SD 5) years). The age at death of miners who worked underground for between 20 and 29 years and of those who worked for more than 30 years was similar. Hence, the difference in the SMRs was due to the difference between the number of deaths that occurred (table 3 ). 
Table 2 Distribution of dead subjects according to age at death, duration of work underground at death, and smoking

\begin{tabular}{|c|c|c|c|c|c|c|c|c|c|c|c|c|c|c|c|}
\hline \multirow[b]{2}{*}{$\begin{array}{l}\text { Cause of death } \\
\text { (ICD-9) }\end{array}$} & \multirow{2}{*}{$\begin{array}{l}\text { Observed } \\
\text { No of } \\
\text { deaths }\end{array}$} & \multicolumn{5}{|c|}{ Age at death $(y)$} & \multicolumn{4}{|c|}{$\begin{array}{l}\text { Duration of work } \\
\text { underground at } \\
\text { death }(y)\end{array}$} & \multicolumn{5}{|c|}{$\begin{array}{l}\text { Smoking at } 1975 \\
\text { (No of pack-years) }\end{array}$} \\
\hline & & $\geqslant 44$ & $45-49$ & $50-54$ & $\geqslant 55$ & $\begin{array}{l}\text { Date } \\
\text { unknown }\end{array}$ & 0 & $1-19$ & $20-29$ & $\geqslant 30$ & $\begin{array}{l}\text { Non- } \\
\text { smokers }\end{array}$ & $1-9$ & $10-19$ & $20-29$ & $\geqslant 30$ \\
\hline $\begin{array}{l}\text { All causes } \\
\text { Cancer all sites }\end{array}$ & 97 & 3 & 21 & 30 & 35 & 8 & 14 & 12 & 35 & 36 & 5 & 2 & 19 & 35 & 36 \\
\hline $\begin{array}{l}\text { (140-239) } \\
\text { Lung (162) }\end{array}$ & $\begin{array}{l}55 \\
33\end{array}$ & $\begin{array}{l}1 \\
1\end{array}$ & $\begin{array}{r}13 \\
6\end{array}$ & $\begin{array}{l}16 \\
13\end{array}$ & $\begin{array}{l}23 \\
12\end{array}$ & $\begin{array}{l}2 \\
1\end{array}$ & $\begin{array}{l}6 \\
1\end{array}$ & $\begin{array}{l}4 \\
2\end{array}$ & $\begin{array}{l}21 \\
15\end{array}$ & $\begin{array}{l}24 \\
15\end{array}$ & $\begin{array}{l}2 \\
1\end{array}$ & - & $\begin{array}{l}9 \\
8\end{array}$ & $\begin{array}{r}20 \\
9\end{array}$ & $\begin{array}{l}24 \\
15\end{array}$ \\
\hline $\begin{array}{l}\text { Upper respirat } \\
\text { and alimentary } \\
\text { tract cancer }\end{array}$ & tory & & & & & & & & & & & & & & \\
\hline$(140-149,161)$ & $\left\{\begin{array}{l}5 \\
4\end{array}\right.$ & - & 2 & 1 & 2 & - & 2 & 1 & 2 & - & - & - & - & 3 & 2 \\
\hline $\begin{array}{l}\text { Cardiovascular } \\
\text { diseases }\end{array}$ & & - & 1 & - & & - & 1 & 1 & I & $\mathbf{I}$ & - & - & 一 & 2 & 2 \\
\hline $\begin{array}{l}(390-459) \\
\text { Cirrhosis of liver, } \\
\text { alcoholism }\end{array}$ & 16 & 1 & 4 & 2 & 7 & 2 & 4 & 2 & 5 & 5 & 1 & 1 & 2 & 5 & 7 \\
\hline $\begin{array}{l}(571 \cdot 0-3,5) \\
\text { Accidents, other } \\
\text { violence }\end{array}$ & 11 & 1 & 2 & 6 & 1 & 1 & 1 & 3 & 5 & 2 & 2 & - & 1 & 6 & 2 \\
\hline (E800-999) & 5 & - & 1 & 3 & - & 1 & 1 & - & 2 & 2 & - & - & 4 & 1 & - \\
\hline Other causes & 6 & - & 1 & 3 & 2 & - & 1 & 3 & 2 & 一 & - & - & 3 & 2 & 1 \\
\hline Unknown causes & 4 & - & - & - & 2 & 2 & 1 & - & - & 3 & - & 1 & - & 1 & 2 \\
\hline
\end{tabular}

Subjects who worked only at the surface experienced an excess of deaths from upper respiratory and alimentary tract cancer $(S M R=197, N S)$ and for stomach cancer $(S M R=469, N S, p<0 \cdot 10)$ (table 3). These causes showed an excess in smokers of more than 20 pack-years only (SMR $=402$ $(\mathrm{p}<0.05)$ and $954(\mathrm{p}<0.01)$ respectively (table 4)).

Table 5 attempts to elucidate the respective roles of occupational exposure and smoking in lung cancer. An excess of lung cancer was noted only in subjects who worked underground for more than
30 years, in heavy smokers ( $\geqslant 20$ pack-years) who worked underground for any duration and in moderate smokers (one to 19 pack-years) who worked underground for more than 20 years. It seemed that there was a dose-effect relation and an interaction between the two factors. Also, the results obtained supported a multiplicative model between these factors when the duration of work underground was more than 20 years.

Table 6 presents the value of the SMRs according to the duration of work underground and age. At the start of the follow up $45 \cdot 8 \%$ of the subjects

Table 3 Mortality according to duration of work underground

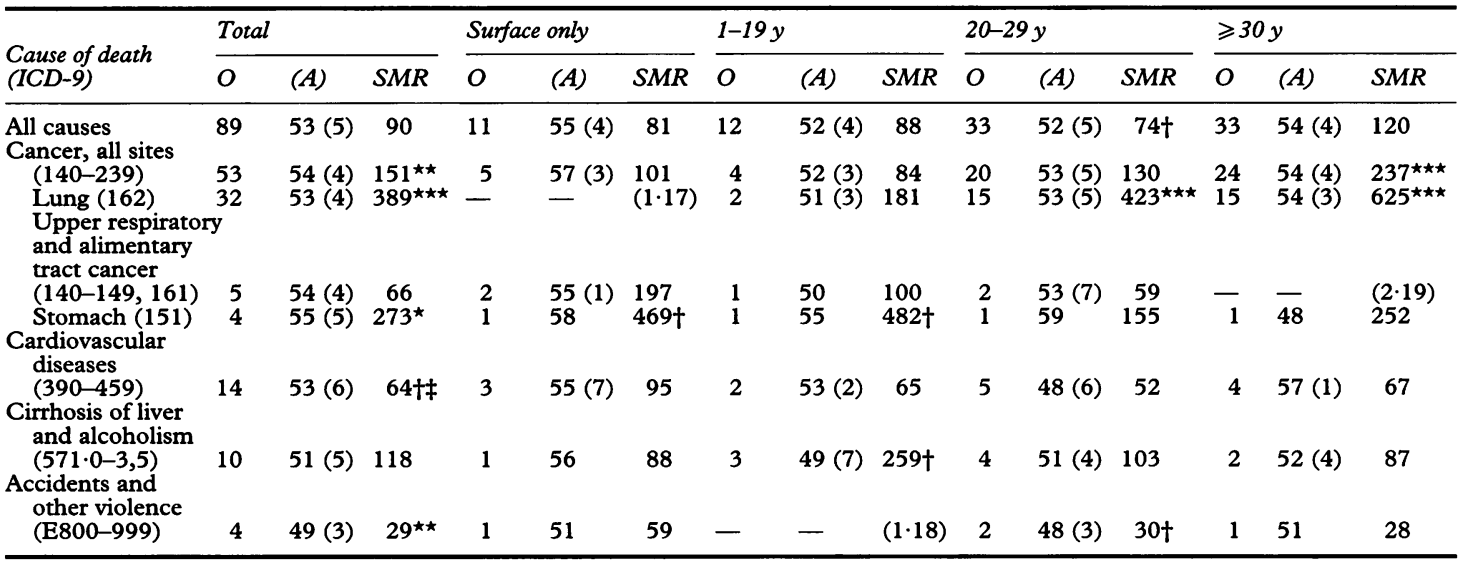

${ }^{\star} \mathrm{p}<0.05 ;{ }^{\star \star} \mathrm{p}<0.001 ;{ }^{\star \star \star} \mathrm{p}<0.001 ;+0.05 \leqslant \mathrm{p}<0.01$

The eight deaths having the date of death unknown $(8 \cdot 2 \%)$ were excluded. $O=$ Number of observed deaths. When $O$ is zero, the number of expected deaths is given in parentheses; (A) = Mean (SD) age at death (y).

$\ddagger$ This value would equal 78 if the deaths having the date of death unknown were taken into account. 
Table 4 Mortality according to duration of work underground and smoking

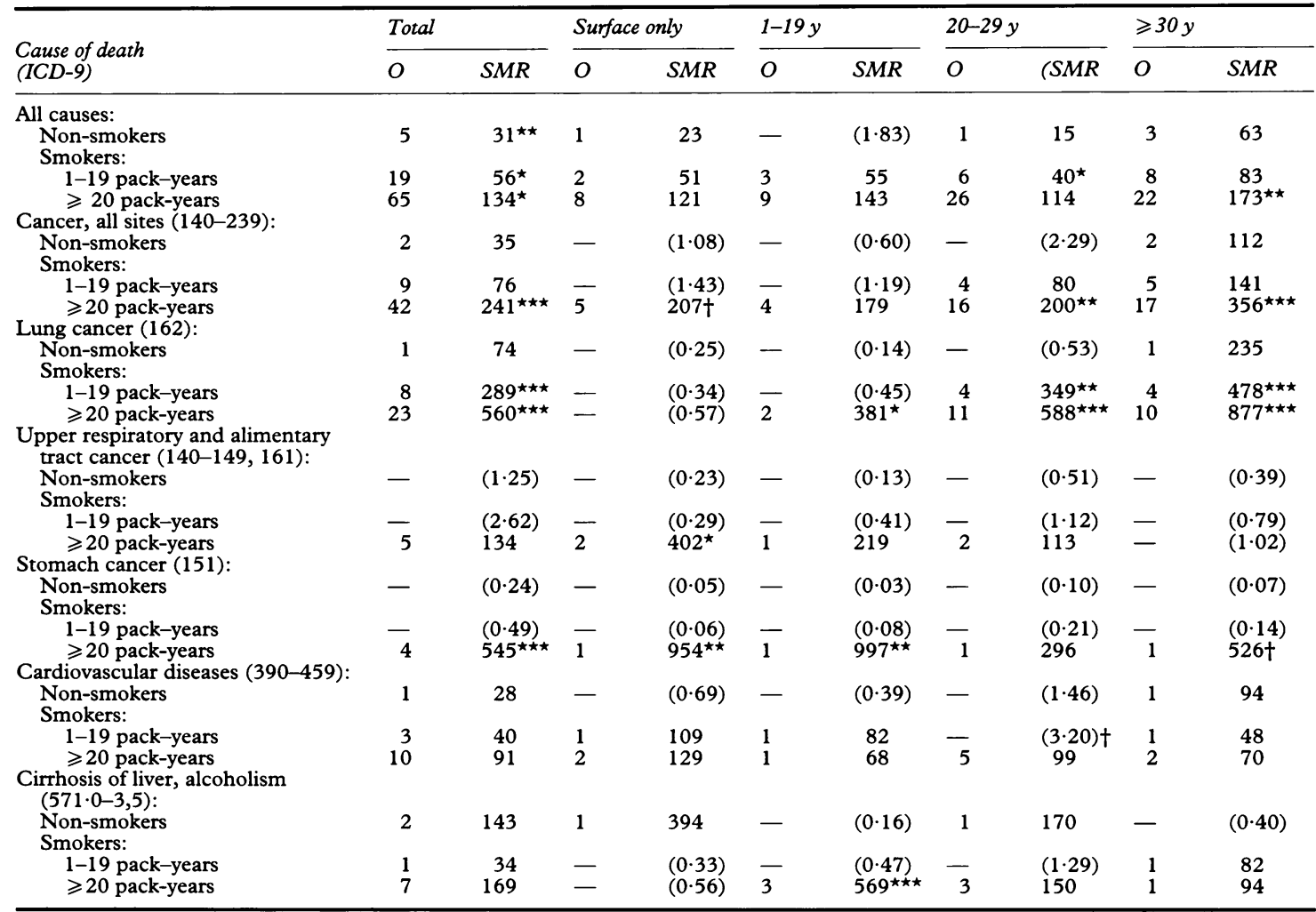

${ }^{\star} \mathrm{p}<0.05 ;{ }^{\star \star} \mathrm{p}<0.01 ;{ }^{\star \star \star} \mathrm{p}<0.001 ;+0.05 \leqslant \mathrm{p}<0.10$.

The eight deaths having the date of death unknown $(8 \cdot 2 \%)$ were excluded.

$\mathrm{O}=$ Number of observed deaths. When $\mathrm{O}$ is zero, the number of expected deaths is given in parentheses.

were aged between 35 and 44 (table 1 ). This age group had a lower than expected mortality from all causes. We think that this was due to selection at hiring and a possible healthy worker effect before the beginning of the follow up. From 45 years the SMR for lung cancer reached $427(p<0.001)$ and it decreased to 320 for the 55-66 age group. Due to this excess of lung cancer, the overall mortality

Table 5 Interaction of smoking and duration of work underground for lung cancer (ICD-9 = 162)

\begin{tabular}{|c|c|c|c|c|c|c|c|c|}
\hline & \multicolumn{5}{|c|}{ Duration of work underground } & \multicolumn{3}{|c|}{ Relative risk (95\% CI) } \\
\hline & Total & Surface only & $\begin{array}{l}1-19 \\
(1)\end{array}$ & $\begin{array}{l}20-29 \\
(2)\end{array}$ & $\geqslant 30$ & $(2) /(1)$ & $(3) /(1)$ & $(3) /(2)$ \\
\hline \multicolumn{9}{|l|}{ SMR: } \\
\hline Non-smokers (4) & 74 & - & - & 一 & 235 & - & 一 & - \\
\hline \multicolumn{9}{|l|}{ Smokers: } \\
\hline 1-19 pack-years (5) & $289^{\star \star \star}$ & - & - & $349^{\star \star}$ & $478^{\star \star \star}$ & - & - & \multirow{3}{*}{$\begin{array}{l}1 \cdot 37 \\
(0 \cdot 3-6 \cdot 7) \\
1 \cdot 49 \\
(0 \cdot 6-3 \cdot 9)\end{array}$} \\
\hline$\geqslant 20$ pack-years $(6)$ & $560 \star \star \star$ & - & $381^{\star}$ & $588^{\star \star \star}$ & $877 \star \star \star$ & $\begin{array}{l}1 \cdot 54 \\
(0 \cdot 3-10)\end{array}$ & $\begin{array}{l}2 \cdot 30 \\
(0 \cdot 5-15)\end{array}$ & \\
\hline $\begin{array}{l}\text { Relative risk: }(5) /(4) \\
\text { Relative risk: }(6) /(4) \\
\text { Relative risk (95\% CI): (6)/(5) }\end{array}$ & $\begin{array}{c}3.91 \dagger \\
7 \cdot 57 \dagger \\
1.94 \\
(0 \cdot 8-4 \cdot 8)\end{array}$ & $\overline{-}$ & - & $\begin{array}{l}- \\
1 \cdot 68 \\
(0.5-6 \cdot 4)\end{array}$ & $\begin{array}{c}2.03 \dagger \\
3.73 \dagger \\
1.83 \\
(0.5-7 \cdot 1)\end{array}$ & & & \\
\hline
\end{tabular}

${ }^{\star} \mathrm{p}<0.05 ;{ }^{\star \star} \mathrm{p}<0.01 ;{ }^{\star \star \star} \mathrm{p}<0.001$.

†These figures seemed interesting, but they were calculated with non-significant SMRs (for non-smokers, in line (4)).

Relative risk = ratio of SMRs.

Although all the relative risks given in this table were not significant due to small numbers, interaction between duration of work underground and tobacco consumption showed that the smokers of 1-19 pack-years who worked underground for between 20 and 29 had an SMR of 349. In an additive model, the smokers of more than 20 pack-years who worked underground for over 30 years would have an $\mathrm{SMR}=349+(478-349)+(588-349)=717$. In a multiplicative model, this last group would have an $\mathrm{SMR}=349 \times 1 \cdot 37$ $\times 1.68=803$. Although the two values were close, the value found (877) supported a multiplicative model. 
Table 6 Mortality from all causes and that from lung cancer (ICD-9 = 162) according to duration of work underground and to age

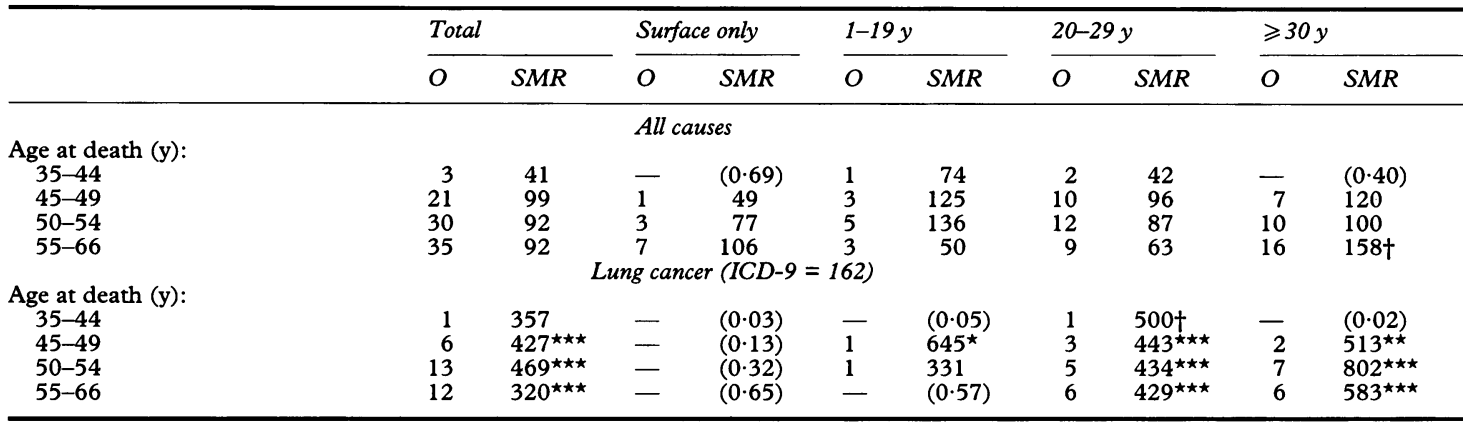

${ }^{\star} \mathrm{p}<0.05 ;{ }^{\star \star} \mathrm{p}<0.01 ;{ }^{\star \star \star} \mathrm{p}<0.001 ;+0.05 \leqslant \mathrm{p}<0.10$

The eight deaths having the date of death unknown $(8 \cdot 2 \%)$ were excluded.

$\mathbf{O}=$ Number of observed deaths. When $\mathrm{O}$ is zero, the number of expected deaths is given in parentheses.

was close to that expected from 45 years old (when we took into account the eight subjects who had an unknown date of death), in the calculations.

We examined whether a decrease in a lung function index at the start of follow up was related to subsequent mortality for all causes and for lung cancer. Lung function and respiratory symptoms were investigated recently by Pham et al. ${ }^{18}$ In our analysis, we considered only three indicesnamely, VC, $\mathrm{FEV}_{1}$, and $\mathrm{FEV}_{1} / \mathrm{VC}$. Table 7 shows the values of the SMRs for subjects having all the three indices normal and for those having one index decreased. The value of an index was considered as normal or decreased if it was either

Table 7 Mortality from all causes and from lung cancer for different durations of work underground and the value of lung function at the start of the follow up (1975)

\begin{tabular}{|c|c|c|c|c|c|c|c|c|}
\hline & \multicolumn{2}{|c|}{ Total } & \multicolumn{2}{|c|}{ Surface only } & \multicolumn{2}{|c|}{$1-19 y$} & \multicolumn{2}{|c|}{$\geqslant 20 y$} \\
\hline & $O$ & $S M R$ & $O$ & $S M R$ & $O$ & $S M R$ & $O$ & $S M R$ \\
\hline \multirow{2}{*}{\multicolumn{9}{|c|}{ Non-smokers: }} \\
\hline & & & & & & & & \\
\hline $\mathrm{VC}, \mathrm{FEV}_{1}$, and $\mathrm{FEV}_{1} / \mathrm{VC}$ normal (a) & 4 & $41 \dagger$ & 1 & 57 & - & $(1 \cdot 02)$ & 3 & 43 \\
\hline VC decreased (b) & - & $(3.59) \dagger$ & - & $(0 \cdot 76)$ & - & $(0 \cdot 40)$ & - & $(2 \cdot 42)$ \\
\hline $\begin{array}{l}\text { FEV }_{1} \text { decreased (b) } \\
\text { FEV, /VC decreased (b) }\end{array}$ & - & $(3 \cdot 06) \dagger$ & - & $(0 \cdot 27)$ & - & $(0 \cdot 39)$ & - & $(2 \cdot 40)$ \\
\hline $\begin{array}{l}\text { FEV }_{1} / \text { V decreased (b) } \\
\text { Smokers } 1-19 \text { pack-years: }\end{array}$ & 1 & 26 & - & $(0.59)$ & & $(0 \cdot 47)$ & 1 & 37 \\
\hline $\begin{array}{l}\text { Smokers } 1-19 \text { pack-years: } \\
\text { VC, } F E V_{1} \text {, and } F E V_{1} / V C \text { normal (a) }\end{array}$ & \multicolumn{8}{|c|}{ Smokers 1-19 pack-years: } \\
\hline VC decreased (b) & 6 & 62 & - & $(1 \cdot 09)$ & 1 & 50 & 5 & $\begin{array}{l}03 \\
75\end{array}$ \\
\hline $\mathrm{FEV}_{1}$ decreased (b) & 7 & 74 & - & $(0.35)$ & 2 & 97 & 5 & 71 \\
\hline $\mathrm{FEV}_{1} /$ VC decreased (b) & 6 & $44^{\star}$ & 1 & 72 & 2 & 70 & 3 & $32^{\star}$ \\
\hline \multicolumn{9}{|l|}{ Smokers $\geqslant 20$ pack-years: } \\
\hline VC, $F E V_{1}$, and $F E V_{1} / V C$ normal (a) & 14 & 90 & 4 & 145 & 1 & 57 & 9 & 81 \\
\hline VC decreased (b) & 32 & $172^{\star \star}$ & 2 & 103 & 5 & 173 & 25 & $182^{\star \star}$ \\
\hline $\mathrm{FEV}_{1}$ decreased (b) & 36 & $183^{\star \star \star}$ & 4 & $313^{\star}$ & 6 & $213 t$ & 26 & $167^{\star \star}$ \\
\hline \multirow{2}{*}{$\mathrm{FEV}_{1} / \mathrm{VC}$ decreased (b) } & 40 & $167^{\star \star}$ & 3 & 112 & 7 & $225^{\star}$ & 30 & $165^{\star \star}$ \\
\hline & \multirow{2}{*}{\multicolumn{6}{|c|}{ Lung cancer $(I C D-9=162)$}} & & \\
\hline Non-smokers: & & & & & & & & \\
\hline VC, $\mathrm{FEV}_{1}$, and $\mathrm{FEV}_{1} / \mathrm{VC}$ normal (a) & - & $(0 \cdot 79)$ & - & $(0 \cdot 15)$ & - & $(0 \cdot 08)$ & - & $(0.57)$ \\
\hline VC decreased (b) & - & $(0 \cdot 30)$ & - & $(0 \cdot 07)$ & - & $(0.03)$ & - & $(0 \cdot 20)$ \\
\hline $\mathrm{FEV}_{1}$ decreased (b) & - & $(0 \cdot 26)$ & - & $(0.02)$ & - & $(0.03)$ & - & $(0 \cdot 21)$ \\
\hline FEV 1 /VC decreased (b) & 1 & 320 & - & $(0 \cdot 05)$ & - & $(0 \cdot 03)$ & 1 & 432 \\
\hline \multicolumn{9}{|l|}{ Smokers 1-19 pack-years: } \\
\hline VC, $\mathrm{FEV}_{1}$, and $\mathrm{FEV}_{1} / \mathrm{VC}$ normal (a) & 4 & $348^{\star \star}$ & - & $(0 \cdot 14)$ & - & $(0 \cdot 13)$ & 4 & $452^{\star \star \star}$ \\
\hline VC decreased (b) & 3 & $366^{\star}$ & - & $(0 \cdot 10)$ & - & $(0 \cdot 17)$ & 3 & $540^{\star \star}$ \\
\hline $\mathrm{FEV}_{1}$ decreased (b) & 2 & 251 & - & $(0.03)$ & - & $(0 \cdot 17)$ & 2 & $331 t$ \\
\hline $\mathrm{FEV}_{1}$ /VC decreased (b) & 2 & 184 & - & $(0 \cdot 12)$ & - & $(0 \cdot 23)$ & 2 & $262^{\circ}$ \\
\hline \multicolumn{9}{|l|}{ Smokers $\geqslant 20$ pack-years: } \\
\hline VC, $\mathrm{FEV}_{1}$, and $\mathrm{FEV}, / \mathrm{VC}$ normal (a) & 4 & $304^{\star}$ & - & $(0 \cdot 23)$ & - & $(0 \cdot 14)$ & 4 & $426^{\star \star}$ \\
\hline VC decreased (b) & 13 & $815^{\star \star \star}$ & - & $(0 \cdot 17)$ & 1 & & 12 & $1018^{\star \star \star}$ \\
\hline $\mathrm{FEV}_{1}$ decreased (b) & 14 & $830^{\star \star \star}$ & - & $(0 \cdot 11)$ & 2 & $852^{\star \star \star}$ & 12 & $893^{\star \star \star}$ \\
\hline $\mathrm{FEV}_{1} / \mathrm{VC}$ decreased (b) & 15 & $739 \star \star \star$ & - & $(0 \cdot 24)$ & 1 & 387 & 14 & $911^{\star \star \star}$ \\
\hline
\end{tabular}


Table 8 Mortality from all causes according to duration of work underground and the presence of a respiratory symptom at the start of the follow up (1975)

\begin{tabular}{|c|c|c|c|c|c|c|c|c|}
\hline & \multicolumn{2}{|c|}{ Total } & \multicolumn{2}{|c|}{ Surface only } & \multicolumn{2}{|c|}{$1-19 y$} & \multicolumn{2}{|c|}{$\geqslant 20 y$} \\
\hline & $O$ & $S M R$ & $O$ & $S M R$ & $O$ & $S M R$ & $O$ & $S M R$ \\
\hline \multicolumn{9}{|l|}{ Non-smokers: } \\
\hline Subjects without symptoms & 3 & $30^{\star}$ & - & $(2 \cdot 32)$ & - & $(1 \cdot 21)$ & 3 & 46 \\
\hline Cough only & - & $(0 \cdot 22)$ & - & - & - & $(0 \cdot 15)$ & - & $(0.07)$ \\
\hline Cough and phlegm & - & $(1.54)$ & - & - & - & $(0 \cdot 16)$ & - & $(1 \cdot 38)$ \\
\hline Chronic bronchitis & 1 & 49 & - & $(0 \cdot 31)$ & - & $(0 \cdot 13)$ & 1 & 63 \\
\hline Wheezing & 1 & 53 & 1 & 212 & - & $(0 \cdot 16)$ & - & $(1 \cdot 23)$ \\
\hline Asthma & - & $(0 \cdot 73)$ & - & - & - & - & - & $(0 \cdot 73)$ \\
\hline No of acute pulmonary episodes $=1-2$ & - & $(1 \cdot 84)$ & - & $(0 \cdot 22)$ & - & $(0 \cdot 13)$ & - & $(1.50)$ \\
\hline No of acute pulmonary episodes $\geqslant 3$ & 2 & 294 & 1 & $455 \dagger$ & - & $(0 \cdot 07)$ & 1 & 257 \\
\hline Dyspnoea stage 1-2 & 1 & 39 & 1 & $4063^{\star \star \star}$ & - & $(0 \cdot 20)$ & - & $(2 \cdot 30)$ \\
\hline Dyspnoea stage $\geqslant 3$ & - & - & & & & & & \\
\hline \multicolumn{9}{|l|}{ Smokers 1-19 pack-years: } \\
\hline Subjects without symptoms & 4 & $33^{\star}$ & 1 & 39 & - & $(2 \cdot 26)$ & 3 & 41 \\
\hline Cough only & 2 & 77 & - & $(0.03)$ & 2 & 234 & - & $(1 \cdot 72)$ \\
\hline Cough and phlegm & 4 & 89 & - & $(0 \cdot 10)$ & - & $(0 \cdot 71)$ & 4 & 108 \\
\hline Chronic bronchitis & 7 & 77 & 6 & 92 & - & $(0 \cdot 22)$ & 1 & 41 \\
\hline Wheezing & 7 & 74 & 1 & $(0.54)$ & 1 & $(1 \cdot 04)$ & 5 & 63 \\
\hline Asthma & 1 & 55 & - & - & - & $(0 \cdot 17)$ & 1 & 61 \\
\hline No of acute pulmonary episodes $=1-2$ & 2 & 41 & - & $(0.34)$ & - & $(0 \cdot 82)$ & 2 & 54 \\
\hline No of acute pulmonary episodes $\geqslant 3$ & 1 & 42 & - & $(0 \cdot 26)$ & - & $(0 \cdot 15)$ & 1 & 50 \\
\hline Dyspnoea stage $1-2$ & 6 & 80 & - & $(0 \cdot 28)$ & 2 & 185 & 4 & 65 \\
\hline Dyspnoea stage $\geqslant 3$ & 1 & 68 & - & - & - & - & 1 & 68 \\
\hline \multicolumn{9}{|l|}{ Smokers $\geqslant 20$ pack-years: } \\
\hline Subjects without symptoms & 17 & 137 & 6 & 155 & 2 & 88 & 9 & 144 \\
\hline Cough only & 9 & $180 \dagger$ & 2 & $452^{\star}$ & 1 & 146 & 6 & 155 \\
\hline Cough and phlegm & 6 & 73 & - & $(0 \cdot 74)$ & - & $(1 \cdot 07)$ & 6 & 94 \\
\hline Chronic bronchitis & 24 & $141 \dagger$ & - & $(1 \cdot 04)$ & 3 & 186 & 21 & $146 \dagger$ \\
\hline Wheezing & 22 & 129 & 1 & 84 & 3 & 197 & 18 & 126 \\
\hline Asthma & 4 & 108 & - & $(0 \cdot 26)$ & - & $(0.54)$ & 4 & 138 \\
\hline No of acute pulmonary episodes $=1-2$ & 9 & 137 & - & $(0 \cdot 12)$ & 2 & 257 & 7 & 124 \\
\hline No of acute pulmonary episodes $\geqslant 3$ & 5 & 132 & - & - & 1 & 164 & 4 & 126 \\
\hline Dyspnoea stage 1-2 & 22 & $169^{\star}$ & 1 & 172 & 2 & $409^{\star}$ & 19 & $159^{\star}$ \\
\hline Dyspnoea stage $\geqslant 3$ & 2 & 59 & - & $(0.35)$ & 1 & 402 & 1 & 36 \\
\hline
\end{tabular}

Footnotes as for table 7 .

higher or lower than the predicted value. ${ }^{18}$ Calculations were also carried out with other thresholds-namely, $70 \%, 80 \%$, and $90 \%$ of the predicted value. The limit of $100 \%$ of predicted seemed to be the most appropriate because most of the miners still had a higher value than that predicted during the follow up period. ${ }^{18}$ Among nonsmokers and smokers of less than 20 pack-years the death rate for all causes did not differ between workers who had a decreased lung function index and those having all the three indices normal. Heavy smokers ( $\geqslant 20$ pack years) with normal lung function had an increased SMR (equal to 90, NS) compared with the other subjects but it did not exceed the expected value. Among these smokers the SMR equalled about $170(p<0.01)$ for miners who had one of the three indices VC, FEV or $\mathrm{FEV}_{1} / \mathrm{VC}$ reduced. This excess was not found for miners who worked only at the surface except for those having decreased $\mathrm{FEV}_{1}$.

The increase in mortality was also found in moderate smokers (1-19 pack-years) who had worked underground for more than 20 years irrespective of lung function index. Among heavy smokers an excess of lung cancer was also noted in miners who worked underground for less than 20 years. Nevertheless, among those who worked underground for more than 20 years, the SMR was about twice as high for subjects having a reduced lung function index $(900, \mathrm{p}<0.001)$ compared with those having the three functional values normal $(426, \mathrm{p}<0 \cdot 01)$.

Table 8 shows the SMRs for all causes for men who had a respiratory symptom and those who had none at the start of the follow up. Among moderate and heavy smokers, those with a respiratory symptom had an SMR similar to that of symptom free workers. The values of the SMRs were however, generally much higher for heavy than for moderate smokers, but a significant excess of overall mortality was found only for heavy smokers with stage 1-2 dyspnoea. By contrast, the risk of lung cancer was as a whole clearly higher for men having a respiratory symptom than for symptom free subjects (table 9). Due to the small numbers it was not considered suitable to compare the values of the SMRs for various symptoms.

Table 10 presents the values of sensibility, specificity, predictive value of a positive (defined by a decrease in a lung function index or the presence of a respiratory symptom at the start of follow up) or negative test for subsequent mortality from all causes and for that from lung cancer. This analysis was not strictly valid because at the start of the fol- 
Table 9 Mortality from lung cancer (ICD-9 = 162) according to duration of work underground and the presence of a respiratory symptom at the start of the follow up (1975)

\begin{tabular}{|c|c|c|c|c|c|c|c|c|}
\hline & \multicolumn{2}{|c|}{ Total } & \multicolumn{2}{|c|}{ Surface only } & \multicolumn{2}{|c|}{$1-19 y$} & \multicolumn{2}{|c|}{$\geqslant 20 y$} \\
\hline & $O$ & $S M R$ & $O$ & $S M R$ & $O$ & $S M R$ & $O$ & $S M R$ \\
\hline \multicolumn{9}{|l|}{ Non-smokers: } \\
\hline Subjects without symptoms & 1 & 121 & - & $(0 \cdot 19)$ & - & $(0 \cdot 09)$ & 1 & 185 \\
\hline Cough only & - & $(0.02)$ & - & & - & & - & \\
\hline Cough and phlegm & - & $(0 \cdot 12)$ & - & & - & & - & \\
\hline Chronic bronchitis & - & $(0 \cdot 17)$ & - & & - & & - & \\
\hline Wheezing & - & $(0 \cdot 15)$ & - & & - & & - & \\
\hline Asthma & - & $(0 \cdot 06)$ & - & & - & & - & \\
\hline No of acute pulmonary episodes $=1-2$ & - & $(0 \cdot 15)$ & - & & - & & - & \\
\hline No of acute pulmonary episodes $\geqslant 3$ & - & $(0.06)$ & - & & - & & - & \\
\hline Dyspnoea stage $1-2$ & - & $(0 \cdot 21)$ & - & & - & & - & \\
\hline Dyspnoea stage $\geqslant 3$ & - & - & - & & - & & - & \\
\hline \multicolumn{9}{|l|}{ Smokers 1-19 pack-years: } \\
\hline Subjects without symptoms & 1 & 105 & - & $(0 \cdot 22)$ & - & $(0 \cdot 18)$ & 1 & 178 \\
\hline Cough only & - & $(0 \cdot 21)$ & - & & - & & - & \\
\hline Cough and phlegm & 3 & $853^{\star \star \star \star}$ & - & $(0 \cdot 01)$ & - & $(0 \cdot 06)$ & 3 & $1044^{\star \star}$ \\
\hline Chronic bronchitis & 3 & $376^{\star}$ & - & $(0.05)$ & - & $(0.09)$ & 3 & $454^{\star \star}$ \\
\hline Wheezing & 3 & $368^{\star}$ & - & $(0.05)$ & - & $(0 \cdot 13)$ & 3 & $477^{\star \star}$ \\
\hline Asthma & 1 & $642^{\star}$ & - & - & - & $(0.01)$ & 1 & $705^{\star}$ \\
\hline No of acute pulmonary episodes $=1-2$ & 1 & 246 & - & $(0.03)$ & - & $(0.07)$ & 1 & 325 \\
\hline No of acute pulmonary episodes $\geqslant 3$ & 1 & $492 \dagger$ & - & $(0.02)$ & - & $(0.01)$ & 1 & $591^{\star}$ \\
\hline Dyspnoea stage $1-2$ & 2 & $319+$ & - & $(0.03)$ & - & $(0 \cdot 09)$ & 2 & $392^{\star}$ \\
\hline Dyspnoea stage $\geqslant 3$ & 1 & $833^{\star}$ & - & - & - & - & - & $833^{\star}$ \\
\hline \multicolumn{9}{|l|}{ Smokers $\geqslant 20$ pack-years: } \\
\hline Subjects without symptoms & 2 & 191 & - & $(0 \cdot 34)$ & - & $(0 \cdot 19)$ & 2 & $383^{\star}$ \\
\hline Cough only & 4 & $941^{\star \star \star}$ & - & $(0.04)$ & 1 & $1745^{\star \star \star}$ & 3 & $902^{\star \star \star}$ \\
\hline Cough and phlegm & 3 & $437^{\star \star}$ & - & $(0 \cdot 06)$ & - & $(0.09)$ & 3 & $563^{\star \star \star}$ \\
\hline Chronic bronchitis & 9 & $620^{\star \star \star}$ & - & $(0.09)$ & - & $(0 \cdot 14)$ & 9 & $737^{\star \star \star}$ \\
\hline Wheezing & 11 & $758^{\star \star \star}$ & - & $(0 \cdot 10)$ & 1 & $753^{\star}$ & 10 & $823^{\star \star \star}$ \\
\hline Asthma & 1 & 307 & - & $(0.02)$ & - & $(0 \cdot 05)$ & 1 & 393 \\
\hline No of acute pulmonary episodes $=1-2$ & 5 & $3602^{\star \star \star}$ & - & $(0 \cdot 01)$ & - & $(0.06)$ & 5 & $4263^{\star \star \star}$ \\
\hline No of acute pulmonary episodes $\geqslant 3$ & 1 & 309 & - & - & - & $(0 \cdot 05)$ & 1 & 367 \\
\hline Dyspnoea stage $1-2$ & 8 & $712^{\star \star \star}$ & - & $(0 \cdot 05)$ & 1 & $2653^{\star \star \star}$ & 7 & $675^{\star \star \star}$ \\
\hline Dyspnoea stage $\geqslant 3$ & - & $(0 \cdot 29)$ & & & & & & \\
\hline
\end{tabular}

Footnotes as for table 7 .

low up some subjects could have already had a symptomatic lung cancer. These subjects, however, would be few. Indeed, in the study cohort the deaths from lung cancer that occurred during the first two and three years of the follow up period were $9 \cdot 1 \%$ and $15 \cdot 2 \%$ whereas the life expectancy of a person with symptomatic lung cancer is short. The risk of developing distant metastasis in patients with non-metastatic primary adenocarcinoma of the lung treated in 10 French cancer institutes from 1980 to 1984 was $37 \%$ at the end of the first year after diagnosis and $68 \%$ at the end of five years. ${ }^{50}$ Crude survival for subjects with non-small cell carcinoma is $57 \%$ for one year, $36 \%$ for two years, and $21 \%$ for three years. ${ }^{51}$

For mortality from all causes a decrease in a lung function index had a sensibility of about $43.2 \%$ for VC and $50.5 \%$ for $\mathrm{FEV}_{1} / \mathrm{VC}$. The last had a specificity lower than the other indices $(59.6 \% v$ about $70 \%$ ). In terms of respiratory symptoms, only chronic bronchitis, wheezing, and dyspnoea stage $\geqslant 1$ had a sensibility higher than $30 \%$; their specificity was similar to that of VC and FEV (about $70 \%$ ). For all the lung function indices and all the respiratory symptoms considered, the predictive value of a negative test was close to $90 \%$.
The predictive value of a positive test varied between $6 \%$ and $13 \%$. The Youden index was $15.8 \%$ for $\mathrm{FEV}_{1}, 14.0 \%$ for $\mathrm{VC}$, and $9.6 \%$ for $\mathrm{FEV}_{1} / \mathrm{VC}$. It was lower than $5 \%$ for all the respiratory symptoms except for dyspnoea stage $\geqslant 1$ (about 10\%).

For lung cancer the sensibility of the three indices of lung function was slightly higher than their respective value for all causes, but their specificity was similar. In terms of respiratory symptoms sensibility and specificity for lung cancer were similar to those for all causes except for wheezing, which had an increased sensibility $(43.7 \%$ v $32 \cdot 6 \%)$. Predictive value of a negative test equalled about $97 \%$ for all these indices. The predictive value of a positive test varied between $2 \%$ and $5 \%$. The Youden index was about $20 \%$ for VC and $\mathrm{FEV}_{1}$ and $15 \cdot 4 \%$ for $\mathrm{FEV}_{1} / \mathrm{VC}$. This index was 15.5 for wheezing, $10.9 \%$ for chronic bronchitis, and $8 \cdot 1 \%$ for stage $\geqslant 1$ dyspnoea. The other respiratory symptoms had a value of less than $6 \%$. We did not carry out this analysis for miners having the highest risk of lung cancer only (smokers and men who worked underground for more than 20 years) because they already represented most of the cohort members. 
Table 10 Sensibility, specificity, and predictive values of a decrease in a lung function index or of the presence of a respiratory symptom at the start of the follow up (1975) for mortality from all causes and that from lung cancer

\begin{tabular}{|c|c|c|c|c|c|}
\hline & $\begin{array}{l}\text { Sensibility } \\
(\%)\end{array}$ & $\begin{array}{l}\text { Specificity } \\
(\%)\end{array}$ & $\begin{array}{l}\text { Youden } \\
\text { index }\end{array}$ & $\begin{array}{l}P V P \\
(\%)\end{array}$ & $\begin{array}{l}P V N \\
(\%)\end{array}$ \\
\hline \multicolumn{6}{|c|}{ All causes } \\
\hline $\begin{array}{l}\text { Lung function: } \\
\text { VC decreased (a) } \\
\text { FEV, decreased (a) } \\
\text { FEV, /VC decreased (a) }\end{array}$ & $\begin{array}{l}43 \cdot 2 \\
45 \cdot 3 \\
50 \cdot 5\end{array}$ & $\begin{array}{l}70 \cdot 8 \\
70.5 \\
59.6\end{array}$ & $\begin{array}{r}14.0 \\
15.8 \\
9.6\end{array}$ & $\begin{array}{l}12 \cdot 3 \\
12 \cdot 8 \\
10 \cdot 7\end{array}$ & $\begin{array}{l}92.9 \\
93 \cdot 1 \\
92.7\end{array}$ \\
\hline $\begin{array}{l}\text { Respiratory symptom: } \\
\text { Cough only } \\
\text { Cough and phlegm } \\
\text { Chronic bronchitis } \\
\text { Wheezing } \\
\text { Asthma } \\
\text { No of acute pulmonary episodes } \geqslant 1 \\
\text { No of acute pulmonary episodes } \geqslant 3 \\
\text { Dyspnoea stage } \geqslant 1\end{array}$ & \begin{tabular}{r|}
$12 \cdot 6$ \\
$11 \cdot 6$ \\
$34 \cdot 7$ \\
$32 \cdot 6$ \\
$6 \cdot 3$ \\
$22 \cdot 1$ \\
$8 \cdot 4$ \\
$35 \cdot 8$
\end{tabular} & $\begin{array}{l}92 \cdot 3 \\
84 \cdot 3 \\
73 \cdot 9 \\
71 \cdot 8 \\
94 \cdot 7 \\
80 \cdot 7 \\
94 \cdot 0 \\
74 \cdot 4\end{array}$ & $\begin{array}{r}4 \cdot 9 \\
-4 \cdot 1 \\
8 \cdot 6 \\
4 \cdot 4 \\
1 \cdot 0 \\
2 \cdot 8 \\
2 \cdot 4 \\
10 \cdot 2\end{array}$ & $\begin{array}{r}13 \cdot 5 \\
6 \cdot 6 \\
11 \cdot 3 \\
9 \cdot 9 \\
10 \cdot 2 \\
9.9 \\
11 \cdot 8 \\
11 \cdot 8\end{array}$ & $\begin{array}{l}91 \cdot 7 \\
90 \cdot 9 \\
92 \cdot 2 \\
91 \cdot 8 \\
91 \cdot 4 \\
91 \cdot 6 \\
91 \cdot 5 \\
92 \cdot 4\end{array}$ \\
\hline \multicolumn{6}{|c|}{ Lung cancer $(I C D-9=162)$} \\
\hline $\begin{array}{l}\text { Lung function: } \\
\text { VC decreased (a) } \\
\text { FEV, decreased (a) } \\
\text { FEV, /VC decreased (a) }\end{array}$ & $\begin{array}{l}50 \cdot 0 \\
50 \cdot 0 \\
56 \cdot 2\end{array}$ & $\begin{array}{l}70 \cdot 1 \\
69 \cdot 7 \\
59 \cdot 2\end{array}$ & $\begin{array}{l}20 \cdot 1 \\
19 \cdot 7 \\
15 \cdot 4\end{array}$ & $\begin{array}{l}4 \cdot 8 \\
4 \cdot 7 \\
4 \cdot 0\end{array}$ & $\begin{array}{l}97 \cdot 9 \\
97 \cdot 9 \\
97 \cdot 8\end{array}$ \\
\hline $\begin{array}{l}\text { Respiratory symptom: } \\
\text { Cough only } \\
\text { Cough and phlegm } \\
\text { Chronic bronchitis } \\
\text { Wheezing } \\
\text { Asthma } \\
\text { No of acute pulmonary episodes } \geqslant 1 \\
\text { No of acute pulmonary episodes } \geqslant 3 \\
\text { Dyspnoea stage } \geqslant 1\end{array}$ & $\begin{array}{r}12 \cdot 5 \\
18 \cdot 7 \\
37 \cdot 5 \\
43 \cdot 7 \\
6 \cdot 2 \\
25 \cdot 0 \\
6 \cdot 2 \\
34 \cdot 4\end{array}$ & $\begin{array}{l}92 \cdot 0 \\
84 \cdot 8 \\
73 \cdot 4 \\
71 \cdot 8 \\
94 \cdot 6 \\
80 \cdot 6 \\
64 \cdot 3 \\
73 \cdot 7\end{array}$ & $\begin{array}{r}4 \cdot 5 \\
3 \cdot 5 \\
10 \cdot 9 \\
15 \cdot 5 \\
0 \cdot 8 \\
5 \cdot 6 \\
-29 \cdot 5 \\
8 \cdot 1\end{array}$ & $\begin{array}{l}4.5 \\
3 \cdot 6 \\
4 \cdot 1 \\
4.5 \\
3.4 \\
3.8 \\
2.9 \\
3.8\end{array}$ & $\begin{array}{l}97 \cdot 2 \\
97 \cdot 2 \\
97 \cdot 5 \\
97 \cdot 7 \\
97 \cdot 1 \\
97 \cdot 3 \\
93 \cdot 6 \\
97 \cdot 4\end{array}$ \\
\hline
\end{tabular}

${ }^{\star} \mathrm{p}<0.05 ;{ }^{\star \star} \mathrm{p}<0.01 ;{ }^{\star \star \star} \mathrm{p}<0.001 ;+0.05 \leqslant \mathrm{p}<0.10$.

The eight deaths with the date of death unknown were included. PVP = predictive value of a positive test (a decrease in a lung function index or the presence of a respiratory symptom); $P V N=$ a negative test.

(a) Lower than the predicted value.

\section{Discussion}

The cohort studied included at the first examination (1975) only the subjects having normal pulmonary $x$ ray films and no chronic cardiovascular disease. This bias could explain the low mortality from cardiovascular diseases. Unfortunately, it was not possible to estimate this bias. It seemed, however, to have little importance with regard to mortality from all causes. Data for lung cancer was only slightly inaccurate because among the 33 deaths from this cause, the date of death was unknown for one case only $(1 / 33=3.0 \%)$. In terms of occupational exposure, the eight deaths of unknown date were distributed among various groups.

The 41 subjects who were lost to follow up since 1980 and who were excluded in this study did not represent an important bias. Indeed, their age, tobacco consumption, and duration of work underground in 1975 were close to those of the other miners.

The fact that for the 97 dead subjects we had not taken into account the occupational exposure between their last medical examination and their date of death in calculation of the SMRs would not greatly modify the results obtained because the total duration of work underground was weakly underestimated ( 2.5 years on an average). Moreover, many people had retired since 1980 .

The frequency of smokers in the study cohort at the first examination $(83 \cdot 1 \%)$ was slightly higher than that in the French male population (about $80 \%$ in 1982)..$^{49}$ With the method of Axelson and Steenland ${ }^{52}$ and assuming a risk of lung cancer for non-smokers and 10 for smokers (these values were close to the values generally expected ${ }^{53}$ ) the relative risk of the study cohort was 1.03 compared with the French male population. In our study we only considered the tobacco consumption until 1975. In fact, a detailed analysis showed that the total consumption did not greatly change during the follow up period due to an effective antismoking compaign conducted since 1975. Furthermore, because in this study people were grouped in large categories (never having smoked, smokers of 1 to 19 , and smokers of more than 20 pack-years) nearly all of the subjects remained in the same group during the whole 11 years.

This study confirmed an increased death rate for lung cancer $(S M R=389, p<0.05)$ and for stomach cancer $(S M R=273, p<0.05)$.

ROLE OF GEOGRAPHIC FACTORS AND THE CHOICE OF STANDARD POPULATION

The choice of the standard population is linked to available statistics. Numerous investigators have emphasised the importance of geographic factors. Indeed, the population of an area could have, among other things, an excess mortality due to 
ethnic factors, lifestyle, dietary habits, and air pollution. ${ }^{54-63}$

Lorraine had 2.33 million inhabitants (with 1.16 million men) in $1975 .{ }^{54}$ The Lorraine ore mines and the Lorraine coal mines covered large areas in the two administrative divisions of Meurthe-etMoselle (729 315 inhabitants with 356775 men) and Moselle (one million inhabitants with 506125 men). There were also industrial platforms producing air pollution. These areas had an increased risk of lung cancer (SMRs 146 and $159(p<0.01)$ with reference to the French male population) in the 1971-8 period. ${ }^{54}$ Furthermore, an excess of stomach cancer was also noted (SMRs $=111(p<0.05)$ and $117(\mathrm{p}<0.01))$. Therefore, it would be suitable to choose the population of these administrative divisions as the standard population.

None the less, the choice was not easy. The population of the coalmine district exposed to a fairly high air pollution produced by the industrial platforms of Carling ${ }^{64}$ showed a lung cancer mortality $(1 \cdot 40)$ lower than that of Moselle for the 1980-4 period. ${ }^{55}$ Also, although the most polluted township ${ }^{64}$ experienced the highest risk of lung cancer, the various townships of this district had a very different SMR (between $<0.80$ and $\geqslant 1.25$ with reference to the population of Moselle) even though this area is not large. By contrast, the various iron mine districts showed a homogeneous mortality from lung cancer.

In this study, however, we preferred the French male population for five reasons: (1) SMRs for various districts probably included other workers exposed to some hazards also related to lung cancer; (2) the excess of lung cancer was low compared with that found in the study; (3) there are several other factors that could also play a part, in particular the socio-occupational category. Desplanques reported that unskilled workmen have a life expectancy lower than other workers and there is a correlation between life expectancy and the $\mathrm{SMR}^{65}$; (4) the comparison between various exposure groups in the study cohort would eliminate the different bias; and (5) it allows comparison with the results of other studies on the same areas that also used the French male population as the standard population.

\section{SELECTION AT HIRING AND THE HEALTHY WORKER EFFECT}

The low mortality found for subjects aged less than 45 supported the hypothesis that selection at hiring and a possible healthy'worker effect (until the start of the follow up (1975)) could play a part. Moreover, despite the high excess of lung cancers and of stomach cancers, the overall mortality did not exceed the expected (even if the eight deaths with date of death unknown were included). The overall SMR would equal $71(p<0.01)$ if we assumed that the SMRs for lung cancer and for stomach cancer equalled $100 \%$ and if the eight deaths above were taken into account.

\section{COMPETING RISK}

The miners studied had an increased risk for lung and stomach cancers only. The distributions of age at death from various causes for the cohort studied were totally different from those for the French male population. In our cohort, lung cancer outweighed all the other causes except for stomach cancer (table 2). In the French male population, cardiovascular diseases were more frequent than lung cancer. Also, the frequency of upper respiratory and alimentary tract cancer was appreciable compared with that of lung cancer (about $2 / 3$ until 35 years old, and similar for the 40-54 year age group. Then more lung cancers appeared in the 55-59 year old group ${ }^{44}$ ). This phenomenon could be explained if the risk of upper respiratory and alimentary tract cancer due mainly to smoking only (and possibly to alcohol consumption) was predominated by that of lung cancer caused by the cumulative effects of occupational hazards and smoking.

\section{LATENCY TIME AND THE MINERS MOST AT RISK} FROM LUNG CANCER

The study cohort seemed appropriate because it showed at what ages an increased risk was found for various causes. An increasing death rate for lung cancer was found from 45 years old and persisted after 55 years of age. The excess mortality was found mainly in the miners who began working life young.

There were some subjects who died quite young, a finding reported in several investigations. ${ }^{1626} 66-69$ The correlations between lung function and respiratory symptoms and subsequent mortality seemed to show that the subjects who started work young would be the least resistant or the most exposed. The interpretation was difficult due to a great variation in the amount of exposure between various employments as emphasised by Pham et $a l^{11}$ and Amandus et al. ${ }^{70}$ Edling reported that if an increased risk of lung cancer was noted for smokers and non-smokers, ${ }^{3}$ the heaviest smoking iron min- of ers died earlier and had a slightly shorter induction $N$ latency period for the development of this cancer.

Moreover, this hypothesis was reinforced by the fact that the excess death rate for lung cancer decreased to half after reaching its maximum in miners aged between 45 and $65^{16}$ although the smokers of more than 20 pack-years who worked underground for more than 20 years were still numerous among people older than 65 years. Desplanques, comparing mortality of various 
socioeconomic categories in the French population, reported a similar finding: the differences in life expectancy between the various categories were higher at 35 years old $(36 \cdot 1$ years for all the French population, between 40.9 years for teachers, and 32.9 years for unskilled workmen) than at 60 years old (16.0 years for the French population, between 18.6 years for teachers, and $14 \cdot 4$ years for unskilled workmen). ${ }^{65}$

Numerous investigations have documented the effect of pulmonary function and of respiratory symptoms on different causes of death. ${ }^{35-37} 71$ This study suggested that an impairment of lung function $\left(\mathrm{VC}, \mathrm{FEV}_{1}\right.$, or $\left.\mathrm{FEV}_{1} / \mathrm{VC}\right)$ could give an indication of lung cancer and result in an early treatment. Moreover, when lung function could not be measured, a respiratory symptom, in particular wheezing, also represented a good index. Screening of subjects at risk raises a genetic problem and the use of biochemical and biological markers. ${ }^{147273}$

Alternatively what would be the variation in the death rate for other causes when compared with that of lung cancer. Mur et al found that the proportionate mortality ratio (PMR) for cirrhosis of the liver was at a maximum (1.37, NS) for the $40-49$ age group, then it decreased to 0.59 (NS) for the 50-59 age group, and finally increased again to 1.16 (NS) for the 60-69 age group; it reached a second maximum of $1.82(p<0.05)$ for those 70-79 years old. These authors found a significantly increased mortality from stomach cancer for the 40-49 age class only (PMR = 327).

\section{ROLE OF ADDITIONAL HAZARDS PRODUCED BY}

DIESEL ENGINES AND EXPLOSIVES

Diesel engines and explosives ${ }^{11}$ have been used in the mine from about 1970. Several investigators showed a relation between prolonged exposure to polycyclic aromatic hydrocarbons, fuel, $\mathrm{NO}_{\mathbf{x}}, \mathrm{CO}$, $\mathrm{SO}_{2}$ and lung function, respiratory symptoms (particularly chronic cough, chronic phlegm, dyspnoea, and wheeze), and mortality. ${ }^{59} 7475$ To estimate their role we compared the results reported by Mur et al ${ }^{16}$ for the 1960-76 period and those of our study for the $1975-85$ period.

Mur et al found that lung cancer in the 1970-6 period had an SMR of about 200 (NS) for subjects aged between 26 and 55, $431(p<0.05)$ for the 56-65 age group, and $239(p<0.05)$ for men older than 66. In our study, we found SMRs of 427 ( $<$ < $0.001), 469(\mathrm{p}<0.001)$ and $320(\mathrm{p}<0.001)$ for $45-49,50-54$ and 55-66 year old groups. Thus subjects in our study died younger. There was also an increased mortality from stomach cancer. Our study showed an SMR of $273(p<0.05)$ whereas Mur et al found no excess (PMR = 94 for 1960-76 period although a significant PMR (327, p < 0.05) was noted for the $40-49$ age group).
ROLE OF SMOKING AND OCCUPATIONAL EXPOSURE This study reported an interaction with smoking. Also, the results presented in table 5 supported a multiplicative relative risk model between tobacco consumption and duration of work underground when this was more than 20 years. This was expected because there are many hazards in the two factors. These findings also indicated a threshold value. ${ }^{76}$

In analyses where smoking was taken into account (tables 4 to 9), the values of the SMRs for non-smokers were underestimated because in the standard population used here about $80 \%$ of subjects were smokers. ${ }^{49}$ The values of the SMRs for smokers were slightly overestimated $(1 \cdot 2$ according to the method of Axelson and Steerland. ${ }^{52}$ ). We were tempted to estimate this bias for non-smokers but numbers were too small. Furthermore, no excess of lung cancers was found for smokers of less than 20 pack-years who worked underground for less than 20 years.

\section{ROLE OF VARIOUS HAZARDS}

Iron ore miners have been exposed to multiple occupational hazards: dusts, radon daughters, ferric oxide, polycyclic aromatic hydrocarbons, diesel fumes, $\mathrm{NO}_{\mathrm{x}}, \mathrm{CO}, \mathrm{SO}_{2}$, etc. Furthermore, there are also other factors such as smoking, alcohol consumption, and air pollution at home.

The effects of some of these hazards have been studied in mice and hamsters. Some authors reported that ferric oxide and silica, combined or not with benzo(a)pyrene, were carcinogens. ${ }^{231-34}$ Studies in animals could give useful information. Possible interaction between different hazards-for example, between smoking and occupational exposure, however, could greatly change the risk. ${ }^{428}$ Also, the time span was reduced in animal investigations. Thus when a constituent was not found to be a carcinogen in an animal study, its effect on humans could not automatically be ruled out.

Like Mur et $a l^{16}$ we do not think that ferric oxide has a role. Indeed, in a retrospective study on 10403 iron ore (haematite) miners in the United States, Lawler et al ${ }^{20}$ noted no excess of lung cancer (SMR 100 and 88 for underground and surface workers) when there was no significant radon exposure, a strict smoking prohibition underground, an aggressive silicosis control programme, and no diesel fuel underground. These authors found a significantly increased mortality from stomach cancer (SMR 167 and 181 for underground and surface workers) in reference to United States white men. Nevertheless, this excess disappeared when the appropriate county death rate was used as a reference, except for Finnish born miners.

Comparison with the results of other studies was interesting. The frequencies of various causes of 
death reported by Chen et $a l^{21}$ in iron ore (haematite) miners in China (of 490 dead underground miners, $42 \%$ were from silicosis and silicotuberculosis, $20 \%$ from cancer including $5.9 \%$ for lung cancer) were different from those in our study (all cancers $56 \cdot 7 \%$, lung cancer $34.0 \%$ ). They found an increased death rate for lung cancer similar to that of our study (SMR $370 v 389$ ). Jobs with heavy exposure to dust and radon daughters showed an SMR of 420. As in our study, they also noted that the risk increased with the amount of dust exposure among current smokers, and no excess of lung cancer existed in unexposed workers (SMR 120). On the contrary, they did not find an excess of stomach cancer in underground miners. These differences could be explained by the fact that the hazards, the ore constituents, and the work conditions would be different between different mines. On the other hand, the age of the cohort studied, the personal factors like smoking, race, lifestyle, and the subjects' age at first employment could also play a part. This was shown by Amandus $e t a^{77}$ in a study on 760 patients with silicosis in North Carolina.

Kinlen and Willows analysed mortality of 1947 Cumbrian iron ore miners over the period 1939-82 in reference to men in England and Wales with similar social class and living mainly in rural areas. They found a significant excess of deaths from tuberculosis, respiratory diseases, and lung cancer. ${ }^{9}$

The role of radon daughters has been studied by many researchers. ${ }^{3-5} 27287879$ Woodward et $a^{26}$ investigated 2574 former uranium mine workers from the Radium Hill mine, which operated in eastern South Australia from 1952 to 1961 . They found a significant SMR for lung cancer (194) with reference to the Australian national population. Howe et al ${ }^{27}$ reported an excess of lung cancer deaths (65 observed $v 34$ expected, $\mathrm{p}<10^{-5}$ ) among 8487 workers employed between 1948 and 1980 at a uranium mine in Canada. Edling ${ }^{3}$ found an increased risk of lung cancer among iron miners (smokers and non-smokers) and he attributed this excess to radon daughters. Radford and Renard reported 50 deaths observed $v 12.8$ expected in 1415 Swedish iron miners exposed to short lived radon daughters at doses close to the currently accepted occupational limit. ${ }^{4}$ The increased risk was close to that of our study (SMR $=389$, $\mathrm{p}<0.001)$ but they attributed the risk to radon daughters.

To examine the role of exposure to dust, it is interesting to enlarge the comparison to coal miners, especially as there were also, in the same area of Lorraine, collieries having a workforce of 23000 people in 1987. Indeed, iron miners and coal miners have been exposed to dust, silica, and radon daughters although the ores are different. Coal miners also had an increased mortality from lung $\stackrel{8}{\stackrel{0}{2}}$ and stomach cancer ${ }^{80-83}$ Ames and Gamble stated that "the data suggest a reverse relation to that pos- $\stackrel{\stackrel{\rho}{\rightarrow}}{\rightarrow}$ tulated, namely, that airway obstruction may be a 0 precondition for stomach cancer and normal pul- 흘 monary function a precondition for lung cancer." $84 \frac{\bar{\rho}}{\widehat{D}}$ Miller and Jacobsen studied 25000 British coal $\stackrel{\mathbb{Q}}{\complement}$ miners over a 22 year period ending in 1980, and found a lung cancer mortality about 5.5 times higher in smokers than in lifelong non-smokers. ${ }^{85}$. This figure was close to that found in our study $\overrightarrow{\vec{\omega}}$ (SMR 289 and 560 for smokers of 1-19 and for $\stackrel{\omega}{\sigma}$ those of more than 20 pack-years). A risk of $\frac{D}{D}$ leukaemia for coal miners (often attributed to $\rightrightarrows$ prolonged exposure to electrical and magnetic 5 fields) was noted by several researchers. ${ }^{86} \mathrm{We}$ did not find this.

The role of dust has been suspected because an $\vec{\circ}$ association between silicosis and pneumoconiosis $v$ and mortality from lung cancer was found in iron, coal, and metal miners. ${ }^{21}$ 23-25 87-93 This association was not found, however, by Miller and Jacobsen, in $Z$ British coal miners. ${ }^{85}$ It seems that, for miners, this association was due to the fact that these diseases $\frac{1}{8}$ were related to the same hazards. Carta $e^{t} a^{94}$ and $\stackrel{\mathbb{Q}}{-}$ Amandus $e t a^{77}$ noted that patients with silicosis $\overrightarrow{0}$ could also have an increased death rate from othe causes (tuberculosis, pneumonia, bronchitis emphysema, asthma). An effect of exposure radon daughters could not be ruled out in these studies.

The effects of polycyclic aromatic hydrocarbons, $\stackrel{0}{\circ}$ and prolonged exposure to fuel, $\mathrm{NO}_{\mathrm{x}}, \mathrm{CO}$, and $\stackrel{\AA}{\circ}$ $\mathrm{SO}_{2}$, have also been investigated. These hazards are $\overrightarrow{\hat{0}}$ not generally isolated and are often associated with $\exists$ dust. The role of polycyclic aromatic hydrocarbons in lung cancer has been studied in various populations, in particular in coke oven workers ${ }^{95}$ and chimney sweeps..$^{96}$ In our current study, the haz- $\frac{\mathbb{D}}{3}$ ards produced by diesel engines and explosives $\dot{\sigma}$ seemed to have a role in lung cancer.

Chen $e t a l^{21}$ indicated that it has not been possible to evaluate the respective roles of dust and of 3 radon daughters due to an overlap of exposure to 0 these hazards. Like Amandus and Costello ${ }^{93}$ we think that a confounding role of radon daughters could not be ruled out. Although radon daughters should have only a modest role for Lorraine iron 0 miners because: (1) The amount of exposure to $N$ radiation was low. Measurements by the European $N$ Steel and Coal Community showed radioactivity of ${ }_{\sigma}^{\omega}$ $0.03 \mathrm{WL}$ (working level) in workplaces and 0.07 WL in normal air reversion (the limit for instanta- $\frac{0}{0}$ neous exposure recommended is $0.3 \mathrm{WL}) .{ }^{41} \stackrel{\oplus}{\rightarrow}$ Several studies showed only a small risk for a low exposure. For example, Schuttmann studied the $\overline{0}$ natural radiation exposure in the German $\mathbb{\Phi}$ Democratic Republic and attributed only about $\frac{?}{\mathrm{P}}$ 
$10 \%$ of lung cancers to this exposure. ${ }^{79}$ Battista et al investigated 1899 subjects of a pyrites mine in central Italy with radon exposure ranging from 0.12 to $0.36 \mathrm{WL}$ in work areas (most values were around $0.2 \mathrm{WL}$ ) and noted an SMR for lung cancer of 137 (NS)..$^{5}$ This excess of deaths was small compared with that reported in our study $(\mathrm{SMR}=$ $389, \mathrm{p}<0.001)$; (2) contrary to the report of Edling $^{3}$ we did not find a risk of lung cancer in non-smokers or among men who worked only at the surface, although the number of subjects was small. Furthermore, an increased risk was found in smokers of one to 19 pack-years when they worked underground for more than 20 years only; (3) it seemed to be established that iron miners have a risk of silicosis and pneumoconiosis (diseases defined in terms of silica or dust deposition in the lung), some respiratory symptoms, and decreases in lung functions that are related to dust, silica, polycyclic aromatic hydrocarbons, fuel, $\mathrm{NO}_{\mathrm{x}} \mathrm{CO}$, and $\mathrm{SO}_{2}$. These diseases and disorders were found to be linked to mortality from lung cancer and therefore lung cancer is probably due to the same hazards. ${ }^{77}$

This work had financial support from the EC Commission (contract No 7248-12003). We thank the Lorraine Iron mines staff for their cooperation. We also thank JC Henquel and $M$ Marchand for their technical assistance, $Y$ Hauquiert and D Bertrand for data keyboarding, $P$ Labriet for verification of data, and A Boyd for help with the English.

1 Boyd JT, Doll R, Faulds JS, et al. Cancer of the lung in iron ore (haematite) miners. Br f Ind Med 1970;27:97-105.

2 Goldsmith DF, Guidotti TL, Johnston DR. Does occupational exposure to silica cause lung cancer? $A m \mathcal{F}$ Ind Med 1982;3:423-40.

3 Edling C. Lung cancer and smoking in a group of iron ore miners. Am f Ind Med 1982;3:191-9.

4 Radford EF, St Clair Renard KG. Lung cancer in Swedish iron miners exposed to low doses of radon daughters. $N$ Engl f Med 1984;310:1485-94.

5 Battista G, Belli S, Carboncini F, et al. Mortality among pyrite miners with low-level exposure to radon daughters. Scand $\mathcal{F}$ Work Environ Health 1988;14:280-5.

6 Gurevich MA. Primary cancer of the lung in iron ore miners. Sov Med 1967;30:71-6.

7 Jorgensen HS. A study of mortality from lung cancer among miners in Kiruna 1950-1970. Work Environment Health 1973;10:126-33.

8 St Clair Renard KG. Respiratory cancer mortality in an ironore mine in northern Sweden. Ambio 1974;2:67-9.

9 Kinlen LJ, Willows AN. Decline in the lung cancer hazards: a prospective study of the mortality of iron ore miners in Cumbria. Brf Ind Med 1988;45:219-24.

10 Axelson O, Sjöberg A. Cancer incidence and exposure to iron oxide dust. F Occup Med 1979;21:419-22.

11 Pham QT, Beigbeder R, Deniau R, Mur JM. Etude de l'incidence à long terme des basses teneurs de nuisances gazeuses sur l'appareil pulmonaire. Méthodologie d'une enquête épidémiologique dans les mines de fer de Lorraine. Archives des Maladies Professionelles 1976;37:393-404.
12 Pham QT, Mur JM, Beigbeder R, Deniau R, Leonet $\mathrm{O}$. Incidence à long terme de basses teneurs de nuisances gazeuses sur l'appareil respiratoire. Résultats d'une cnquête épidémiologique chez les ouvriers des mines de fer du Bassin de Lorraine. Rev Epidémiol Santé Publique 1977; 25:255-73.

13 Pham QT, Gaertner M, Mur JM, Braun P, Gabiano M, Sadoul $P$. Incidence of lung cancer among iron miners. European fournal of Respiratory Diseases 1983;64:534-40.

14 Pham QT, Mur JM, Chau N, Gabiano M, Henquel JC, Teculescu D. Prognostic value of acetylcholine challenge test: a prospective study. $B r$ F Ind Med 1984;41:267-71.

15 Pham QT, Mur JM, Teculescu D, et al. A longitudinal study of symptoms and respiratory function tests in iron miners. European fournal of Respiratory Diseases 1986;69:346-54.

16 Mur JM, Meyer-Bisch C, Pham QT, et al. Risk of lung cancer among iron ore miners: a proportional mortality study of 1,075 deceased miners in Lorraine, France. 7 Occup Med 1987;29:762-8.

17 Pham QT, Chau N, Patris A, et al. Prospective mortality study among iron miners. Cancer Detect Prev 1991;15: 449-54.

18 Pham QT, Teculescu D, Chau N. Iron miners-a ten year follow-up. Eur F Epidemiol 1992;8:594-600.

19 Pham QT, Caillier I, Chau N, Teculescu D, Patris A Trombert B. Mortalité des mineurs de fer en Lorraine. Archives des Maladies Professionelles (in press.)

20 Lawler AB, Mandel JS, Schuman LM, Lubin JH. A retrospective cohort mortality study of iron ore (hematite) miners in Minnesota. 7 Occup Med 1985;27:507-17.

21 Chen SY, Hayes RB, Liang SR, Li QG, Stewart PA, Blair A Mortality experience of haematite mine workers in China. $\mathrm{Br}$ f Ind Med 1990;47:175-81.

22 Bubenicek L. Recherches sur la constitution et la répartition des minerais de fer dans l'Aalénier de Lorraine. Sciences de la Terre 1961;8:5-204.

23 Faulds JS, Stewart MJ. Carcinoma of the lung in haematite miners. Fournal of Pathology and Bacteriology 1956; 72:353-65.

24 Gurevich MA, Slinchenko NZ. Morphology of cancer of the lung in workers of ore miners. Arkh Patol 1971;33:22-6.

25 Cavelier C, Mur JM, Cericola C. Le cancer bronchique chez les mineurs de fer: sélection bibliographique d'enquêtes épidémiologiques et d'études expérimentales. Cahiers de Notes Documentaires 1980;100:363-71.

26 Woodward A, Roder D, McMichael AJ, Crouch P, Mylvaganam A. Radon daughter exposures at the Radium Hill uranium mine and lung cancer rates among former workers, 1952-87. Cancer Causes Control 1991;2:213-20.

27 Howe GR, Nair RC, Newcombe HB, Miller AB, Abbatt JD Lung cancer mortality $(1950-80)$ in relation to radon daughter exposure in a cohort of workers at the Eldorado Beaverlodge uranium mine. $\mathcal{F}$ Natl Cancer Inst 1986;77: 357-62.

28 Sherson D, Sigsgaard T, Overgaard E, Loft S, Poulsen HE, Jongeneelen FJ. Interaction of smoking, uptake of polycyclic aromatic hydrocarbons, and cytochrome P4501A2 activity among foundry workers. Br F Ind Med 1992;49:197-202.

29 Steenland $K$, Thun $M$. Interaction between tobacco smoking and occupational exposures in the causation of lung cancer 7 Occup Med 1986;28:110-8.

30 Campbell JA. Effects of precipited silica and of iron oxide on the incidence of primary lung tumours in mice. $B M F$ 1940;2:275-80.

31 Feron VJ, Emmelot P, Vossenaar T. Lower respiratory tract tumors in Syrian golden hamsters after intratracheal instillations of diethylnitrosamine alone and with ferric oxide. Eur 7 Cancer 1972;8:445-9.

32 Henri MC, Port CD, Kaufman DG. Importance of physical properties of benzo(a)pyrene-ferric oxide mixtures in lung tumor induction. Cancer Res 1975;35:207-17.

33 Nettesheim P, Creasia DA, Mitchell TJ. Carcinogenic and cococarcinogenic effects of inhaled synthetic smog and ferric oxide particles. F Natl Cancer Inst 1975;55:159-66.

34 Saffiotti U, Montesano R, Sellakumar AR, et al. Respiratory tract carcinogenesis induced in hamsters by different dose levels of benzo(a)pyrene and ferric oxide. 7 Natl Cancer Inst 1972;49:1199-204

35 Vollmer WM, McCamant LE, Johnson LR, Buist AS. Respiratory symptoms, lung function, and mortality in a screening center cohort. Am f Epidemiol 1989;129:1157-69.

36 Beaty TH, Newill CA, Cohen BH, et al. Effects of pulmonary function on mortality. Fournal of Chronic Diseases 1985;38 703-10. 
37 Ebi-Kryston $\mathrm{KL}$. Respiratory symptoms and pulmonary function as predictors of 10 -year mortality from respiratory disease, cardiovascular disease, and all causes in the Whitehall study. 7 Clin Epidemiol 1988;41:251-60.

38 Brille D, Bolt W, Greve LH, Minette A, Sartorelli E. Questionnaire de la Haute Autorité de la CECA pour l'étude de la bronchite et de l'emphysème pulmonaire. Luxembourg; Commission des Communautés Européennes CECA, 1962.

39 CECA. Aide mémoire pour la pratique de la fonction ventilatoire par la spirographie. Collection d'Hygiène et de Médecine du Travail, $\mathrm{n}^{\circ}$ 11, 2e ed. Luxembourg: Commission des Communautés Européennes CECA, 1971.

40 American Thoracic Society. Definitions and classification of chronic bronchitis, asthma and pulmonary emphysema. $\mathrm{Am}$ Rev Respir Dis 1962;85:762-8.

41 Exposition au Radon des travailleurs des mines non-uranifères de la Communauté Européenne-Contrat CCE $n^{\circ}$ 1143-79-L/V (personal communication).

42 Organisation Mondiale de la Santé (OMS). Classification internationale des maladies. 9ème rev. Genève: OMS, vol 1, 1975; vol 2, 1977.

43 Breslow NE, Day NE. Statistical methods in cancer research. Vol II. The design and analysis of cohort studies. Lyon: International Agency for Research on Cancer, 1987. (Sci publ. No 82).

44 INSERM. Statistique des causes médicales de décès, Vol 1: Résultats France entière. Paris: INSERM, 1975-85.

45 Armitage P, Berry G. Statistical methods in medical research. Oxford: Blackwell Scientific Publications, 1987.

46 Junod $B$, Briançon S, Houot $O$, Doumergue $T$. Un modèle pour l'évaluation des tests de dépistage. Le cas des tumeurs colorectales. Rev Epidémiol Santé Publique 1989;37:49-59.

47 Fox Software. FoxPro, V 2.0. Perrysburg, Ohio: Fox Software, 1989.

48 SPSS Inc. SPSS User's Guide, 2nd ed. New York: MacGrawHill, 1986.

49 Service des Statistiques, des Etudes et des Systèmes d'Information (SESI). Les consommateurs de boissons alcooliques et de tabac Enquête sur la santé et les soins médicaux 1980-1981. Solidarité Santé. Cahiers statistiques, No 1, 1984.

50 Malissard L, Nguyen TD, Jung GM, et al. Localized adenocarcinoma of the lung: a retrospective study of 186 nonmetastatic patients from the French Federation of Cancer Institutes: the Radiotherapy Cooperative Group. Int $\mathcal{f}$ Radiat Oncol Biol Phys 1991;21:369-73.

51 Talton BM, Constable WC, Kersh L. Curative radiotherapy in non-small cell carcinoma of the lung. Int $\mathcal{F}$ Radiat Oncol Biol Phys 1990;19:15-21.

52 Axelson $\mathrm{O}$, Steenland $\mathrm{K}$. Indirect methods of assessing the effects of tobacco use in occupational studies. Am F Ind Med 1988;13:105-8.

53 Surgeon General. The health consequences of smoking. Washington: Cancer US Department of Health and Human Services, 1982

54 Rezvani A, Doyon F, Flamant R. Atlas de la mortalité par cancer en France (1971-1978). Paris: Les Editions INSERM, 1986.

55 Briançon S, Castel O, Hilico C, Schléret Y. Atlas de la mortalité en Lorraine. Observatoire régional de la santé et des affaires sociales en Lorraine. Nancy: INSEE, 1989.

56 Hill C. Overview of available data on diet and cancer mortality in France. Tumori 1990;31:299-305.

57 Davies DL, Hoel D, Fox J, Lopez A. International trends in cancer mortality in France, West Germany, Italy, Japan, England and Wales, and the USA. Lancet 1990;336:474-81.

58 Menotti A. Food patterns and health problems: health in southern Europe. Ann Nutr Metab 1991;35 (suppl 1):69-77.

59 Ferry R, Festy B, Dab W, et al. ERPURS (Evaluation des Risques de la Pollution Urbaine sur la Santé). lère phase: effets à court et moyen terme de la pollution atmosphérique sur la santé. Analyse des études épidémiologiques publiées entre 1980 et 1991. Paris: Observatoire Régional de Santé d'Ile-deFrance, 1992.

60 Shannon HS, Hertzman C, Julian JA, et al. Lung cancer and air pollution in an industrial city-a geographical analysis. Can $\mathcal{F}$ Public Health 1988;79:255-9.

61 Colley JRT, Brasser LJ. Pollution atmosphérique et maladies respiratoires chroniques chez les enfants. Rapport d'une étude de I'OMS: rapports et Etudes Euro 28. Organisation mondiale de la Santé, Copenhegan: Bureau régional de l'Europe, 1981.
62 Buffler PA, Cooper SP, Stinnett S, et al. Air pollution and lung cancer mortality in Harris County, Texas, 1979-1981. Am $\mathcal{E}$ Epidemiol 1988;128:683-99.

63 Smith GH, Williams FLR, Lloyd OLL. Respiratory cancer $\mathscr{O}$ and air pollution from iron foundries in a Scottish town: an $\bar{C}$ epidemiological and environmental study. $\mathrm{Br} \mathcal{F}$ Ind Med 1987;44:795-802.

64 Patris A, Chau N, Téculescu D, et al. La pollution atmo- $\frac{\bar{\omega}}{}$ sphérique dans la plateforme industrielle de Carling en $\mathbb{D}$ 1984. Pollution Atmosphérique 1987;116:373-81.

65 Desplanques G. La mortalité des adultes suivant le milieu social. Юొ 1955-1971 Paris; INSEE, 1976. N. 195 des collections de l'INSEE.

66 Forastiere F, Lagorio S, Michelozzi P, Perucci CA, Axelson A. Mortality pattern of silicotic subjects in the Latium region, Italy. $\mathrm{Br} F$ Ind $\mathrm{Med}$ 1989;46:877-80.

67 Davies JM, Easton DF, Bidstrup PL. Mortality from respiratory cancer and other causes in United Kingdom $O$ chromate production workers. $\mathrm{Br} \mathcal{F}$ Ind $\mathrm{Med} 1991 ; 48: \frac{\Im}{3}$ 299-313.

68 Hansen ES. A cohort study on the mortality of firefighters. $\mathrm{Br} \mathrm{O}$ 7 Ind Med 1990;47:805-9.

69 Barregard L, Sällsten G, Järvholm B. Mortality and cancer $\overrightarrow{-}$ incidence in chloralkali workers exposed to inorganic mercury. Br F Ind Med 1990;47:99-104.

70 Amandus HE, Piacitelli G. Dust Exposures at US Surface $\vec{V}$ Coal Mines in 1982-1983. Arch Environ Health 1987;42:374-81.

71 Kellie SE, Attfield MD, Hankinson $\pi$, Castellan RM. Spirometry variability criteria association with respiratory $Z$ morbidity and mortality in a cohort of coal miners. $A m$ f $O$ Epidemiol 1987;125:437-44.

72 Nicholson WJ. Research issues in occupational and environ- $\frac{\mathbb{D}}{7}$ mental cancer. Arch Environ Health 1984;39:190-202.

73 Vineis P. Uses of biochemical and biological markers in occupational epidemiology. Rev Epidémiol, or et Santé Publique 1992;40:S63-9.

74 Schilling CJ, Tams IP, Schilling RSF, Nevitt A, Rossiter G Wilkinson B. A survey into the respiratory effects of pto $\omega$ longed exposure to pulverised fuel ash. $\mathrm{Br} f$ Ind $M$ $1988 ; 45: 810-7$

75 Magnani C, Pannett B, Winter PD, Coggon D. Application of a job-exposure matrix to national mortality statistics for lung cancer. $B r$ F Ind Med 1988;45:70-2.

76 Mur JM. Epidemiology of respiratory hazards: recent advances. Rev Epidémiol et Santé Publique 1992;40:S27-41.

77 Amandus HE, Shy C, Wing S, Blair A, Heineman EF Silicosis and lung cancer in North Carolina dusty trades $\overrightarrow{\vec{A}}$ workers. Am $\mathcal{F}$ Ind Med 1991;20:57-70.

78 Cothern CR. Indoor air radon. Rev Environ Contam Toxicol 1990;111:1-60.

79 Schuttmann W. Die Strahlenbelastung der Atemwege durch die Radionuklide der Umwelt. $Z$ Erkr Atmungsorgane 1983;161:248-56.

80 Meijers JM, Swaen GM, Slangen J, Van Vliet K, Sturmans F. $\frac{\mathbb{D}}{3}$ Long-term mortality in miners with coal workers' pneumo-? coniosis in the Netherlands: a pilot study. Am $\mathcal{F}$ Ind Med 1991;19:43-50.

81 Ames RG, Gastric cancer and coal mine dust exposure. A case-control study. Cancer 1983;52:1346-50.

82 Atuhaire LK, Campbell MJ, Cochrane AL, Jones M, Moore F. Specific causes of death in miners and ex-miners of the Rhondda Fach 1950-80. Br ₹ Ind Med 1986;43:497-9.

83 Dechoux J, Wantz JM. Le cancer bronchique chez les mineurs des houillères du Bassin de Lorraine. Rev Mal Respir 1985; 2:69-74.

84 Ames RG. Gamble JF. Lung cancer, stomach cancer, and $\vec{N}$ smoking status among coal miners. A preliminary test of a $\sigma$ hypothesis. Scand 7 Work Environ Health 1983;9:443-8.

85 Miller BG, Jacobsen M. Dust exposure, pneumoconiosis, and mortality of coalminers. Br f Ind Med 1985;42:723-33.

86 Gilman PA, Ames RG, McCawley MA. Leukemia risk among $\omega$ US white male coal miners. A case-control study. $\mathcal{F}$ Occup Med 1985;27:669-71.

87 James WLR. Primary lung cancer in South Wales coal-workers with pneumoconiosis. $\mathrm{Br} \mathcal{F}$ Ind $M e d$ 1955;12:87-91.

88 Myers CE. Anthracosilicosis and bronchogenic carcinoma. Dis Chest 1967;57:800-6.

89 Scarano D, Fadali $M$, Lemole G. Carcinoma of the lung and $\frac{T}{T}$ anthracosilicosis. Chest 1972;62:251-4.

90 Mooney FS. Coal worker's pneumoconiosis and carcinoma of $\overrightarrow{\mathbb{D}}$ the lung. Lancet 1975;1:43. 
91 Cardesi E, Provana A. Contributo al problema dell'associazione silicosicarcinoma pulmonare. Pathologica 1978;70: 377-401.

92 Finkelstein M, Kusiak R, Suranyi G. Mortality among miners receiving workmen's compensation for silicosis in Ontario: 1940-1975. F Occup Med 1982;24:663-7.

93 Amandus $\mathrm{H}$, Costello J. Silicosis and lung cancer in US metal miners. Arch Environ Health 1991;46:82-9.

94 Carta P, Cocco PL, Casula D. Mortality from lung cancer among Sardinian patients with silicosis. $\mathrm{Br} F$ Ind $\mathrm{Med}$ 1991;48:122-9.

95 Chau N, Bertrand JP, Mur JM, et al. Mortality in retired coke oven plant workers. $\mathrm{Br} \mathcal{F}$ Ind Med 1993;50:127-135.

96 Gustavsson P, Gustavsson A, Hogstedt C. Excess of cancer in Swedish chimney sweeps. Br f Ind Med 1988;45:777-81.

Accepted 21 December 1992

\section{Correspondence and editorials}

The British fournal of Industrial Medicine welcomes correspondence relating to any of the material appearing in the journal. Results from preliminary or small scale studies may also be published in the correspondence column if this seems appropriate. Letters should be not more than 500 words in length and contain a minimum of references. Tables and figures should be kept to an absolute minimum. Letters are accepted on the understanding that they may be subject to editorial revision and shortening.

The journal now also publishes editorials which are normally specially commissioned. The Editor welcomes suggestions regarding suitable topics; those wishing to submit an editorial, however, should do so only after discussion with the Editor. 